\title{
Chemopreventative strategies targeting the MGMT repair protein: Augmented expression in human lymphocytes and tumor cells by ethanolic and aqueous extracts of several Indian medicinal plants
}

\author{
SURYAKANT K. NITURE, U. SUBRAHMANYESWARA RAO and KALKUNTE S. SRIVENUGOPAL \\ Center for Cancer Biology, Department of Pharmaceutical Sciences, \\ Texas Tech University Health Sciences Center, Amarillo, TX, USA
}

Received May 19, 2006; Accepted June 20, 2006

\begin{abstract}
O}^{6}$-alkylguanines are potent mutagenic, procarcinogenic and cytotoxic lesions induced by exogenous and endogenous alkylating agents. A facilitated elimination of these lesions by increasing the activity of $\mathrm{O}^{6}$-methylguanineDNA methyltransferase (MGMT) is likely to be a beneficial chemoprevention strategy, which, however, has not been examined. Because, a marginal enhancement of this protein may be adequate for genomic protection, we studied alterations in MGMT activity and expression in human peripheral blood lymphocytes and cancer cell lines induced by water-soluble and alcohol-soluble constituents of several plants with established antioxidant and medicinal properties. Both the ethanolic and aqueous extracts from neem (Azadirachta indica), holy basil (Ocimum sanctum), winter cherry (Withania somnifera), and oregano (Origanum majorana) increased the levels of MGMT protein and its demethylation activity in a time-dependent manner with a maximum of 3-fold increase after 72-h treatment. The extracts from gooseberry (Emblica officinalis), common basil (Ocimum basilicum), and spearmint (Mentha viridis) were relatively less efficient in raising MGMT levels. Increased levels of MGMT mRNA accounted at least, in part, for the increased activity of the DNA repair protein. The herbal treatments also increased glutathione S-transferase-pi (GSTP1) expression, albeit to a lesser extent than MGMT.
\end{abstract}

Correspondence to: Dr Kalkunte S. Srivenugopal, Department of Pharmaceutical Sciences, Texas Tech University Health Sciences Center, 1400 Wallace Blvd., Amarillo, TX 79106, USA

E-mail: kalkunte.srivenugopal@ttuhsc.edu

Abbreviations: MGMT, $\mathrm{O}^{6}$-methylguanine-DNA methyltransferase; DTT, dithiothreitol; BCNU, 1,3-Bis(2-chloroethyl)-1-nitrosourea; $\mathrm{BG}, \mathrm{O}^{6}$-benzylguanine; HPBL, human peripheral blood lymphocytes; GSTP1, glutathione-S-tranferase P1; DMBA, 7,12-Dimethylbenzanthracene

Key words: MGMT, base excision repair, chemoprevention, chemoprotection, oxidative stress, antioxidants, alkylation damage, glutathione, GST
These data provide the first evidence for the upregulation of human MGMT by plant constituents and raise the possibility of rational dietary approaches for attenuating alkylationinduced carcinogenesis. Further, they reveal the putative antioxidant responsiveness of the MGMT gene in human cells.

\section{Introduction}

Genomic DNA is constantly exposed to various alkylating agents that can elicit mutagenic, recombinogenic, carcinogenic, toxic, and teratogenic effects (1). These DNA damaging agents could be of exogenous (dietary, environmental and therapeutic) or endogenous origin. For example, DNA-reactive heterocyclic amines, nitrosamines and polyaromatic hydrocarbons are highly pervasive in cooked food $(2,3)$ and tobacco smoke (4). The dimethylnitrosamine which is formed during food preparation and nitroso-nor-nicotine and 4-(methylnitrosoamino)-1-(3-piridyl)-1-butanone are the predominant alkylating agents produced during smoking (5). Alkylation of DNA can occur at various sites, however alkylation of the $\mathrm{O}^{6}$-position of guanine bears the strongest mutagenic potential (6). This lesion is most critical, because, $\mathrm{O}^{6}$-alkylguanines preferentially pair with thymine, resulting in $\mathrm{G}: \mathrm{C}$ to $\mathrm{A}: \mathrm{T}$ transitions upon DNA replication $(7,8) . \mathrm{O}^{6}$-alkylguanines are formed to different extents, depending on the agent, but reach at maximum $8 \%$ of total alkylations (6). Similarly, $\mathrm{O}^{4}$ methylthymine generated in smaller amounts by alkylating agents causes $A: T \rightarrow G: C$ transitions (9). In humans, low but measurable amounts of $\mathrm{O}^{6}$-akylguanine have been found in the DNA of both normal and tumor tissues $(10,11)$. S-adenosylmethionine, the endogenous methyl group donor has been estimated to generate 10-30 $\mathrm{O}^{6}$-methylguanine residues per day in a mammalian cell (12). Other endogenous methylating agents may arise from nitrosation of amino acids or bile acids; betaine and choline are other sources (13). Cellular repair of $\mathrm{O}^{4}$-alkylthymine, $\mathrm{O}^{6}$ - methylguanine and $\mathrm{O}^{6}$-alkylguanines in DNA is mediated by $\mathrm{O}^{6}$-methylguanine-DNA methyltransferase (MGMT, also called $\mathrm{O}^{6}$-alkylguanine-DNA alkyltransferase) in all organisms, including humans $(1,8,14)$. MGMT remains the most critical repair protein in cellular defense against alkylation damage of DNA. This protein functions by a unique stoichiometric and suicidal reaction mechanism in 
which the alkyl groups bound to the $\mathrm{O}^{6}$-position of guanine are transferred to a cysteine in its active site, resulting in the direct restoration of the normal base and self-inactivation of MGMT protein $(1,8,14,15)$. MGMT, which is highly expressed in human cancers, is also a central determinant of tumor resistance to many clinically used anticancer alkylating agents because the $\mathrm{O}^{6}$-methylguanine and $\mathrm{O}^{6}$-chloroethylguanine lesions induced by methylating (temozolomide, dacarbazine, and procarbazine) and chloroethylating (BCNU and 1-(2chloroethyl)-3-cyclohexyl-1-nitrosourea) agents, respectively, are excellent substrates for MGMT (16). In the case of bifunctional alkylators such as BCNU, the removal of chloroethyl adducts by MGMT prevents the production of cytotoxic DNA interstrand cross links (16). Therefore, inhibition of MGMT by powerful pseudosubstrates such as $\mathrm{O}^{6}$-benzylguanine (BG) has emerged as a prominent strategy to enhance the cytotoxicity of alkylating agents (17).

The literature on MGMT's role in preventing carcinogenesis and oncogenic mutations is vast and has been extensively reviewed $(14-16,18,19)$. Briefly, mice overexpressing the MGMT gene display significant reduction of spontaneous tumors and marked resistance to developing cancers (brain tumors, lymphomas, and liver cancers) after alkylator treatments (20-22). Interestingly, MGMT transgenic mice appear to live longer (23). Animals and mouse lines deficient in MGMT gene, which were established by gene targeting, exhibit increased sensitivity to alkylating carcinogens (20). Reduced MGMT activity or silencing of the MGMT gene through promoter methylation in human cancers is associated with frequent mutations in K-ras, p53 and ß-catenin genes (24-27). In contrast, reductions of oncogenic mutations in cells with MGMT overexpression have been reported $(28,29)$. Further, several studies have demonstrated significant associations between MGMT genotype, cigarette smoking and increased risk for developing different cancers $(30,31)$. In addition, the biochemical strategy involving the depletion of MGMT using BG followed by administration of alkylating agents, for improving the efficacy of the latter, although promising, is beset with marked toxicity to normal tissues, particularly, the rapidly proliferating hematopoietic system (32). This problem has necessitated a gene therapy approach involving the transfer of BG-resistant MGMT genes (G156A and $\mathrm{P} 140 \mathrm{~K}$ ) into hematopoietic stem cells and make the bone marrow resistant to alkylators $(17,33)$. These gene transduction strategies also underscore the tenet of MGMT as a target for chemoprotection.

Despite these well-established experimental and etiological data on the protection bestowed on human genome, MGMT has received little attention as a target for chemoprevention. Development of dietary compounds as potential cancer chemopreventative agents against alkylating chemicals is highly desirable, due to their safety, low toxicity, and ease of oral intake. Because a variety of antioxidant compounds present in plant extracts modulate the activities of phase-II metabolic and other detoxifying enzymes (34), this study addressed the possible upregulation of MGMT expression in human peripheral blood mononuclear cells and cancer cell lines by the crude fractions isolated from various plants which have demonstrated antioxidant and healing properties in Indian traditional medicine (35). Many of these plants, including neem and holy basil, have shown antimutagenic and anticarcinogenic activity in animal studies $(36,37)$. We demonstrate for the first time that MGMT activity can be augmented significantly by the compounds present in certain medicinal plants.

\section{Materials and methods}

Cell lines and their culture. The human medulloblastoma cell line UW228 was established and provided by Dr Francis AliOsman (Duke University, Durham, NC, USA). The human colon carcinoma cell lines, HT29 and HCT116 and T98G glioblastoma were purchased from the American Type Culture Collection. All cell lines were cultured in Dulbecco's modified Eagle's medium (DMEM) in the presence of antibiotics and $10 \%$ bovine serum in a humidified atmosphere containing $5 \% \mathrm{CO}_{2}$ at $37^{\circ} \mathrm{C}$.

Isolation of human blood mononuclear cells. Buffy coat preparations from healthy volunteers were purchased from the local blood bank and fractionated by Histopaque-1077 (Sigma) gradient centrifugation according to the manufacturer's instructions for isolating HPBLs. The cells were washed twice with RPMI-1640 medium, suspended in the same medium at $5 \times 10^{6}$ cells $/ \mathrm{ml}$, and cultured as above for short-term experiments. Lymphocytes were not activated with a mitogen.

Plant sources and extract preparations. Ocimum sanctum (holy basil) leaf powder, Withania somnifera (winter cherry) root powder, powdered berries of Emblica officinalis (gooseberry) were purchased from Hesh Pharmaceuticals (Mumbai, India). Green leaves of Azadirachta indica (neem), Mentha viridis (spearmint), Ocimum basilicum (common basil), and Origanum majorana (oregano) were collected in India and locally. They were sun dried, and used for extract preparations. Dried leaves were finely ground; these and the herbal powders $(50 \mathrm{~g})$ were soaked overnight in sterile water. The extracts were centrifuged at 10,000 $\mathrm{x} g$ and the supernatants were freeze dried. The lyophilized material was dissolved in sterile water, the clear supernatants were filter sterilized, and the resulting solutions were designated the aqueous extracts. Ethanol fractionation was performed by adding three volumes of $90 \%$ cold ethanol to the crude aqueous extracts, and the precipitates collected there from were dried in a rotary evaporator under vacuum. This material was dissolved in ethanol, filtered through a nylon mesh, and the clear supernatants represented the ethanolic extracts.

HPBLs $\left(10 \times 10^{6}\right.$ cells) were treated with ethanolic extracts of Azadirachta indica $(20 \mu \mathrm{g} / \mathrm{ml})$ and Ocimum sanctum $(10 \mu \mathrm{g} / \mathrm{ml})$ for $30 \mathrm{~h}$. Control and treated cells were pelleted and used for measuring the levels of protein, activity, and mRNA for MGMT were quantified from the control and extract-treated lymphocytes.

Assay of MGMT activity. MGMT activity was measured by the transfer of $\left[{ }^{3} \mathrm{H}\right]$-labeled methyl groups from the $\mathrm{O}^{6}$-position of guanine in DNA to the MGMT protein as described previously (38). Briefly, cell-free extracts were prepared by sonication in MGMT assay buffer [40 mM Tris- $\mathrm{HCl}$ ( $\mathrm{pH} \mathrm{8.0)}$ ], 5\% glycerol, $1 \mathrm{mM}$ EDTA, $20 \mu \mathrm{M}$ spermidine, and $0.5 \mathrm{mM}$ 
DTT] followed by centrifugation at $10,000 \times \mathrm{g}$ for $10 \mathrm{~min}$. The extracts (50-200 $\mu \mathrm{g}$ of protein) were supplemented with $\left[{ }^{3} \mathrm{H}\right]$ DNA enriched for $\mathrm{O}^{6}$-methylguanine $(3 \mu \mathrm{g} ; 10,000 \mathrm{cpm})$, and incubated for $30 \mathrm{~min}$ at $37^{\circ} \mathrm{C}$. The reactions were quantitated after acid hydrolysis of the DNA substrate and the collection of protein precipitates and counting of radioactivity. The activity in the linear portion of the curve was used to calculate the specific activity (pmol $\mathrm{CH}_{3}$ groups removed/mg protein).

GSTP1 assay. GSTP1 enzyme activity was determined in $100 \mathrm{mM}$ potassium phosphate buffer $(\mathrm{pH}$ 6.5) containing $1 \mathrm{mM}$ Na-EDTA, $1 \mathrm{mM}$ GSH and $1 \mathrm{mM}$ chlorodinitrobenzene $(\mathrm{CDNB})$ in a final volume of $1 \mathrm{ml}$ using the well-established spectrophotometric assay (39). The reactions were initiated by addition of control or treated cell extracts (100-200 $\mu \mathrm{g}$ ) and changes in absorbance were monitored at $340 \mathrm{~nm}$ over 2 min in a Labomed spectrophotometer. The rates of the spontaneous reactions of GSH with CDNB, determined with reaction mixtures in which the cell extract was replaced with buffer were subtracted from the rates of the enzyme catalyzed reactions. The linear part of the reaction kinetics was used to calculate enzyme activity taking the extinction coefficient of the CDNB-GSH conjugate as $9.6 \mathrm{mM}$.

Western blotting. Following trypsinization, the cell pellets were washed with PBS, and cell extracts were prepared by sonication in $50 \mathrm{mM}$ Tris/ $\mathrm{HCl}$ buffer $(\mathrm{pH} 8.0)$ containing $1 \%$ glycerol, $1 \mathrm{mM}$ EDTA, $0.5 \mathrm{mM}$ PMSF and $2 \mathrm{mM}$ benzamidine followed by centrifugation. Equal protein amounts $(60 \mu \mathrm{g})$ were electrophoresed on $12 \%$ reducing SDS-polyacrylamide gels. Proteins were electrotransferred to Immobilon-P membranes. The membranes were blocked with $3 \%$ non-fat dry milk in Tris-buffered saline (TBS; $\mathrm{pH}$ 8.0) containing 0.1\% Tween-20 for $5 \mathrm{~h}$, and subsequently incubated with mouse anti-MGMT monoclonal antibody (Chemicon International, Temecula, CA) or GSTP1 rabbit polyclonal antibodies (EMD Biosciences, San Diego, CA) at $1 \mu \mathrm{g} / \mathrm{ml}$. Antigen-antibody complexes were visualized by enhanced chemiluminiscence. In most cases, the blots were reprobed with antibodies to $\beta$-actin to assess equal protein loading. Band intensities were quantitated using the VersaDoc Imaging system (Bio-Rad, Richmond, CA).

$R N A$ isolation and RT-PCR. Total RNA was isolated from human tumor cells and lymphocytes using the RNA-Zol reagent (Sigma). The integrity of RNA was verified by electrophoresis on $1 \%$ non-formaldehyde agarose gels at $\mathrm{pH} 8.5$. For RT-PCR, $1 \mu \mathrm{g}$ RNA was reverse-transcribed using an Access Quick RT PCR kit and MuLV reverse transcriptase (Promega, Madison, WI) according to the manufacturer's instructions. The cDNA obtained was amplified using Taq DNA polymerase using the following primers: MGMT, sense 5'-CCTTGGTACTTAAGCTTATGGACAAG and antisense 5'-CTACTGCACGAATTCAG; actin, sense 5'- TGACGGG GTCACCCACACCCACACTGTGCCCATCTA and antisense 5'-CTAGAAGCATTTGCGGTGGACGATGGAGGG. PCR involved $5 \mathrm{~min}$ of denaturation at $94^{\circ} \mathrm{C}$, followed by 34 cycles at $94^{\circ} \mathrm{C}$ for $1 \mathrm{~min}, 60^{\circ} \mathrm{C}$ for $1 \mathrm{~min}$, and $72^{\circ} \mathrm{C}$ for $1 \mathrm{~min}$, and a final extension at $72^{\circ} \mathrm{C}$ for $10 \mathrm{~min}$ (40) using a Biometra
A

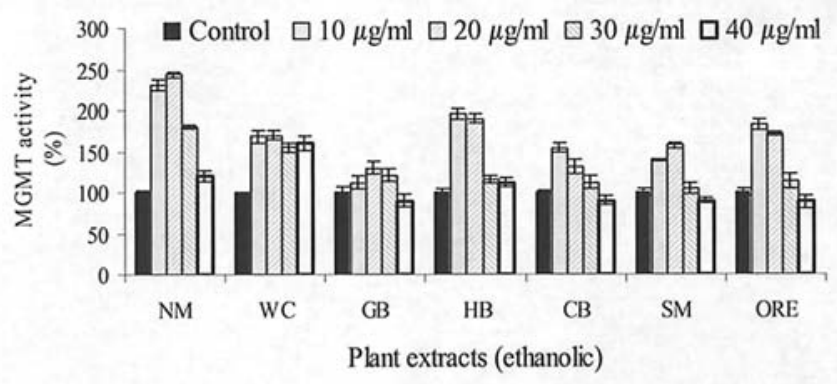

B

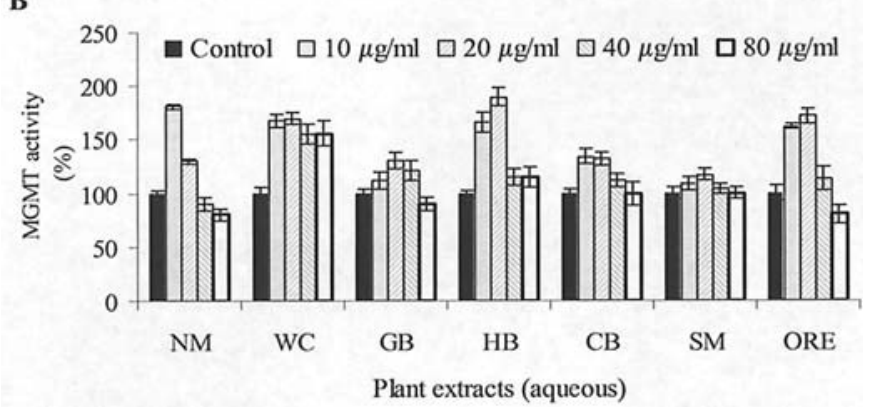

Figure 1. Effect of water or ethanol extracted plant compounds on the MGMT activity in HT29 colon cancer cells. Cells were exposed for $24 \mathrm{~h}$ to ethanolic extracts $(10-40 \mu \mathrm{g} / \mathrm{ml})(\mathrm{A})$ or aqueous extracts $(10-80 \mu \mathrm{g} / \mathrm{ml})(\mathrm{B})$ prepared from different plants. MGMT activity was determined in the sonicated cell extracts. The results represent the means \pm SD of three separate experiments, and were statistically significant $(\mathrm{P}<0.05)$. NM, neem; WC, winter cherry; GB, gooseberry; HB, holy basil; $\mathrm{CB}$, common basil; SM, spearmint; ORE, oregano.

thermal cycler. The amplified DNA sizes were $800 \mathrm{bp}$ for MGMT and $650 \mathrm{bp}$ for actin. The PCR products were analyzed by electrophoresis on $1.5 \%$ agarose gels and visualized by ethidium bromide staining under UV light.

Statistical analyses. All experiments were performed at least 3 times and the data are shown as mean \pm SD where applicable. Statistically significant differences between groups were determined using the Student's t-test.

\section{Results}

Alterations in MGMT activity in HT29 cells upon treatment with aqueous and ethanolic extracts from various medicinal plants. Initial experiments investigated the effect of phytochemicals present in the water soluble and ethanol soluble extracts prepared from different plants well recognized for their medicinal and antimutagenic properties. These included neem leaves (Azadirachta indica), winter cherry roots (Withania Somnifera), holy basil leaves (Ocimum sanctum), common basil leaves (Ocimum basilicum), berries of gooseberry (Emblica officinalis), spearmint leaves (Mentha viridis), and oregano leaves (Origanum majorana). First, we determined the dose-dependent effects of ethanolic $(10-40 \mu \mathrm{g} / \mathrm{ml})$, and aqueous constituents $(10-80 \mu \mathrm{g} / \mathrm{ml})$ on MGMT activity in HT29 human colon carcinoma cells after 24-h treatment. Fig. 1A shows that the ethanolic extracts from neem, holy basil, and oregano markedly and reproducibly increased the MGMT activity (2-2.5-fold), whereas the extracts from 
A

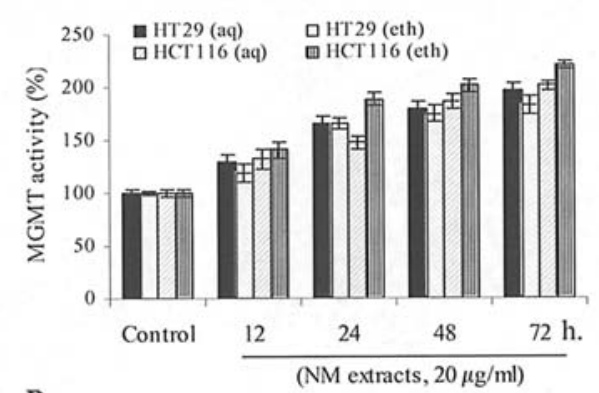

B

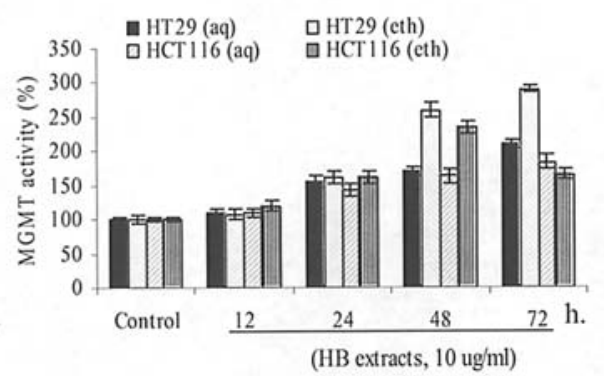

C
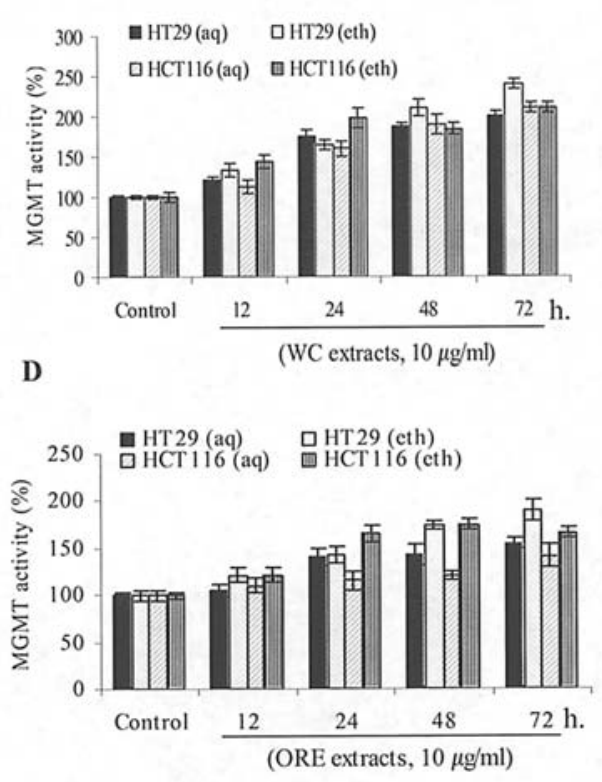

Figure 2. Time-dependent increase in MGMT activity in HT29 and HCT116 cells after treatment with plant extracts. HT29 and HCT116 cells were treated with (A) $20 \mu \mathrm{g} / \mathrm{ml}$ of ethanolic or aqueous neem leaf extracts, (B) $10 \mu \mathrm{g} / \mathrm{ml}$ of ethanolic or aqueous extracts from the leaves of holy basil, (C) $10 \mu \mathrm{g} / \mathrm{ml}$ of ethanolic or aqueous extracts from the roots of winter cherry, (D) $10 \mu \mathrm{g} / \mathrm{ml}$ of ethanolic or aqueous extracts from oregano leaves for 12-72 h. Means \pm SD of MGMT activity computed from three independent experiments are shown.

winter cherry, common basil, and mint were less potent, and the gooseberry fraction was least effective. Treatment with aqueous extracts from these plants elicited similar responses with neem $>$ winter cherry $>$ holy basil $>$ oregano generating greater increases in MGMT activity. The plant compounds responsible for enhancing MGMT activity in aqueous and ethanolic fractions are likely to be the same because the latter enriched mixture was derived from the water soluble extracts.

Kinetics of enhancement in MGMT activity by plant extracts in two tumor cell lines. Next, The HT29 and HCT116 colon carcinoma cell lines were exposed to the aqueous and ethanolic extracts from neem, winter cherry, holy basil and oregano (which caused significant upregulation of MGMT; Fig. 1), and we determined the time course and extent of increase in MGMT activity. These results are shown in Fig. 2. It is clear that both water and ethanol soluble herbal compounds increased the MGMT activity in a gradual and time-dependent manner. The highest increases occurred at $72 \mathrm{~h}$ of continued incubation. Both cell lines were responsive, and a maximal increase of 3-fold occurred in the presence of holy basil ethanolic extracts (Fig. 2B). Among the other plants, neem, winter cherry, and oregano extracts consistently yielded 2.2-, 2.5-, and 2-fold increases in DNA repair activity at $72 \mathrm{~h}$ post treatment. No changes in cell morphology or signs of cell death as determined by trypan blue exclusion were evident during incubation with plant compounds.

Alterations in MGMT protein expression induced by plant extracts in human tumor cell lines. Human MGMT functions by a stoichiometric reaction mechanism in which the number of $\mathrm{O}^{6}$-alkyl lesions repaired equals the number of protein molecules present $(1,15)$. However, this protein is modulated by posttranslational mechanisms such as phosphorylation, which inhibits its activity $(38,41)$. Therefore, to investigate whether the changes induced in MGMT activity by phytochemicals were accompanied by corresponding increases in MGMT protein levels, we performed Western blot analysis at 12, 24, 48 and $72 \mathrm{~h}$ after incubating HT29 cells with the ethanolic and aqueous extracts. The resulting immunoblots are shown in Fig. 3. It is clear that the various plant extracts increased the MGMT protein levels in a progressive and time-dependent manner with the highest levels accumulating at $72 \mathrm{~h}$. The fold enhancement in protein levels relative to the untreated controls is shown above the Western blots. In general, the kinetics of protein accumulation observed in Fig. 3 correlated closely with the time course changes in MGMT activity observed for different plant extracts in the HT29 cell line (Fig. 2A and B). Thus, the ethanolic extracts which were more efficient than aqueous fractions in augmenting MGMT activity (Fig. 2A) also increased the protein levels to a greater extent. Also, the greater induction of MGMT activity by neem, holy basil and the reduced ability of spearmint to do so (Fig. 1B) are well reflected in the Western analysis. These data confirm the induction of MGMT by plant constituents and suggest that among the plants tested, the compounds present in neem, holy basil and winter cherry are more potent in this parameter.

Increased levels of MGMT mRNA in HT29 cells treated with ethanolic plant extracts. To study whether the increased production of MGMT observed in cells treated with phytochemicals results from enhanced gene transcription, we performed RT-PCR in HT29 cells after 72-h exposure to ethanolic extracts. Fig. 4 shows the abundance of MGMT gene transcripts and their quantitation by densitometry. All 


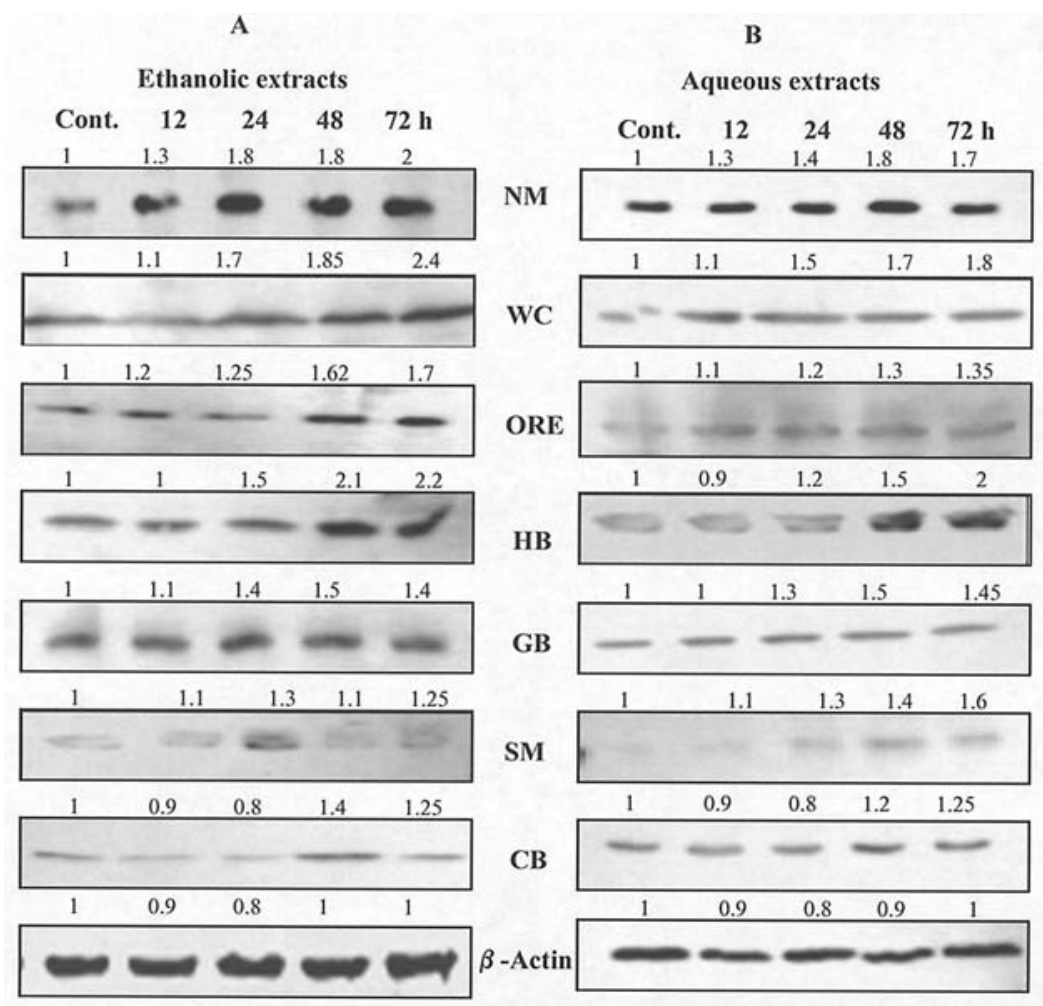

Figure 3. Kinetics of increase in MGMT protein levels after treatment of HT29 cells with ethanolic or aqueous extracts from different plants. Tumor cells were exposed to the ethanolic (A) or aqueous (B) extracts from different plants at optimal amounts determined from the data shown in Fig. 2. At each time-point, the cell pellets were lysed and $50 \mu \mathrm{g}$ protein amounts were electrophoresed and processed for Western blot analysis as described in Materials and methods. The membranes were probed for MGMT using a monoclonal antibody and subsequently with an antibody for actin. The MGMT protein pattern and a representative actin Western blot showing equivalent protein loading are shown. The numbers above the Western blots indicate the fold-changes in MGMT protein as determined by densitometry of the corresponding bands.

C NM WC ORE HB GB SM CB
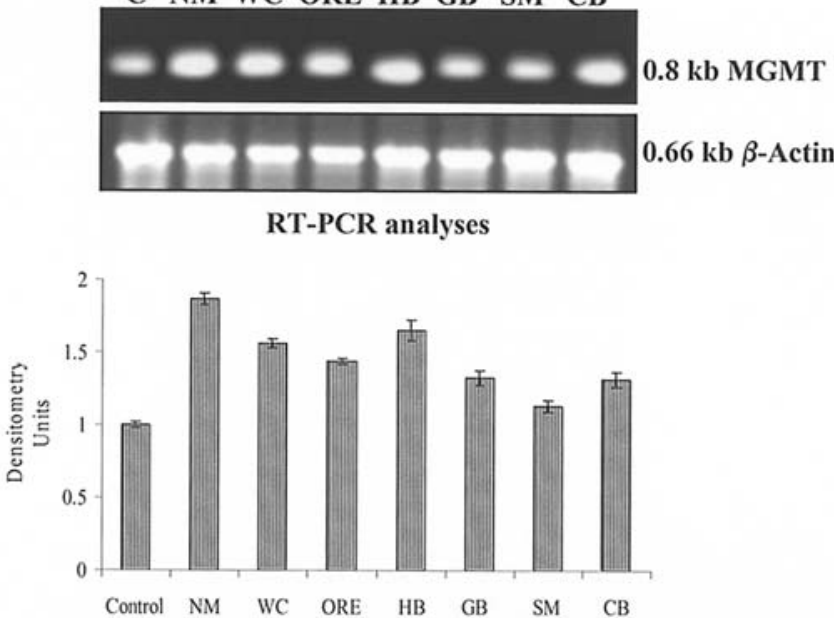

Figure 4. Transcriptional regulation of the MGMT gene by plant extracts. HT29 cells were exposed for $72 \mathrm{~h}$ to the ethanolic extracts from neem (NM), winter cherry (WC), oregano (ORE), holy basil (HB), gooseberry (GB), spearmint $(\mathrm{SM})$, and common basil $(\mathrm{CB})$. Total RNA $(1 \mu \mathrm{g})$ isolated from these and the untreated control (C) cells was subjected to quantitative RT-PCR as described in Materials and methods. The PCR products were electrophoresed on an agarose gel, stained with ethidium bromide and photographed. The relative abundance of MGMT gene transcripts as determined by densitometry is shown in the lower panel.

plant extracts increased the mRNA levels above control, and the highest increments occurred for the neem, holy basil and winter cherry treatments, which also showed marked augment- ation of MGMT activity and protein levels. Collectively, these findings indicate that at least part of the MGMT upregulation by the plant compounds occurred at the transcriptional level.

Upregulation of MGMT by plant extracts in unstimulated human peripheral blood lymphocytes. HPBLs isolated from healthy volunteers served as the normal cell model in our study. For this, HPBLs were exposed to the ethanolic extracts from neem and holy basil for $24 \mathrm{~h}$ and processed for determination of MGMT mRNA, protein and catalytic activity. Neem and holy basil induced an average of 1.9- and 1.6-fold increase in MGMT activity (Fig. 5A), and corresponding increases in MGMT protein (Fig. 5B) in different lymphocyte preparations. The MGMT gene appeared to undergo transcriptional regulation in HPBLs as well, as evident by the increased mRNA levels (Fig. 5C). These data suggest that the selected phytochemicals can raise MGMT expression in human normal tissues and bestow protection against alkylating carcinogens.

Increase in glutathione S-transferase P1 gene expression after phytochemical treatments. Because GSTP1 is a central player in xenobiotic detoxification and is frequently induced by a variety of antioxidant plant compounds (42), we assayed GSTP1 activity and protein expression in HT29 tumor cells and human peripheral blood lymphocytes following phytochemical treatments. The results shown in Fig. 6A demonstrate that ethanolic extracts from different plants caused approximately a 2-fold increase in GST-activity after 72-h incubation. The corresponding aqueous extracts were less efficient (Fig. 6A). 
A

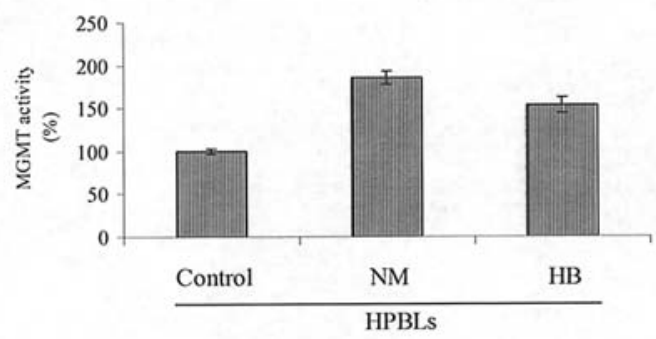

C

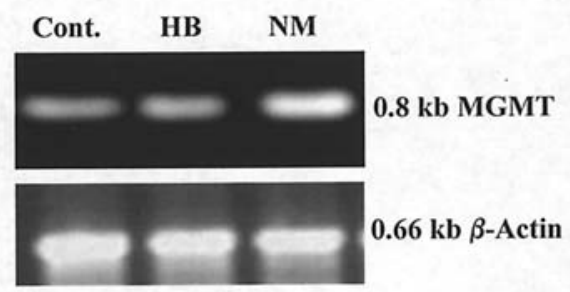

B
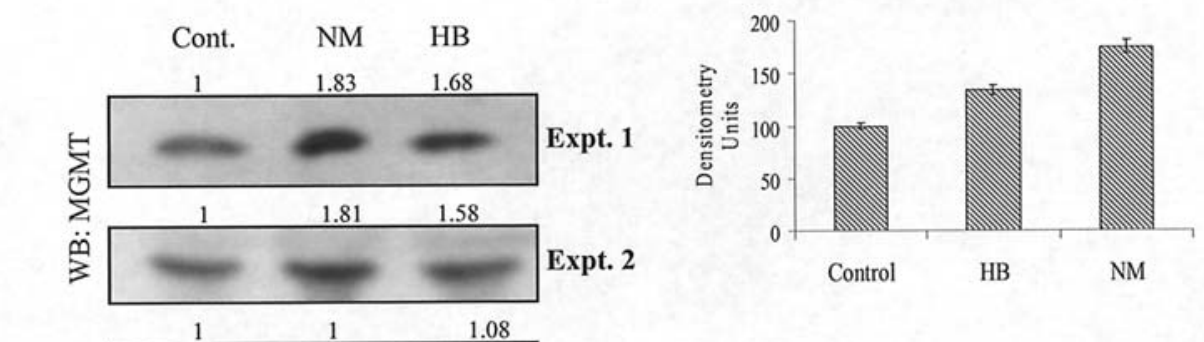

$\beta$-Actin

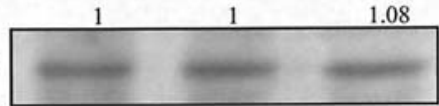

Figure 5. Upregulation of MGMT in human peripheral blood lymphocytes (HPBLs) by plant extracts. HPBLs isolated from healthy donors were exposed to ethanolic extracts from neem (NM) and holy basil (HB) for $24 \mathrm{~h}$. The cells were then processed for the determination of (A) MGMT activity, (B) MGMT protein in two different lymphocyte preparations by Western blot analysis, and (C) MGMT mRNA by RT-PCR analysis. Densitometric quantitation is shown in the lower panel.

A

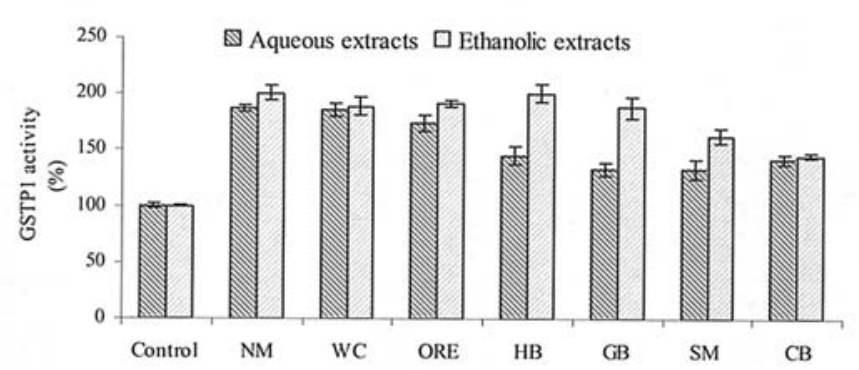

C
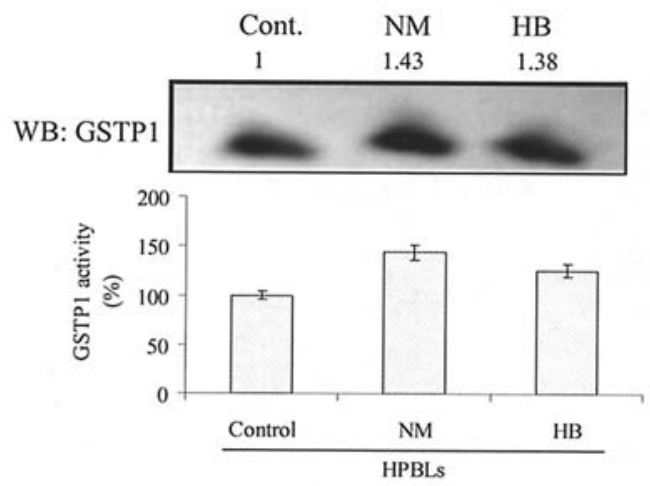

B

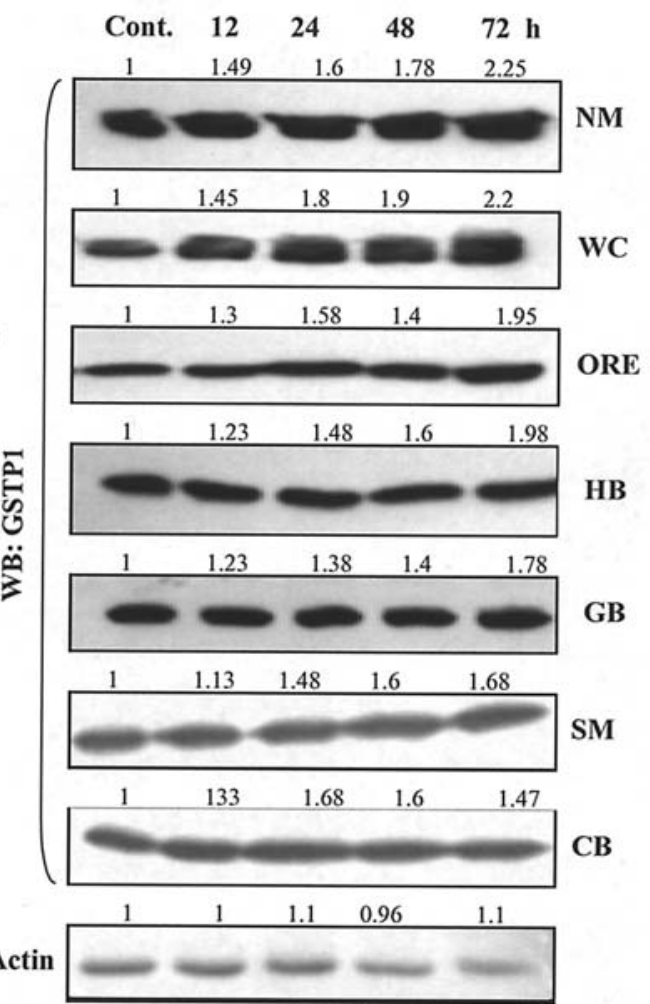

Figure 6. Increased GSTP1 activity and protein levels in HT29 colon cancer cells and human lymphocytes after treatment with plant extracts. (A) GSTP1 activity. HT29 cells were exposed to aqueous or ethanolic extracts from neem (NM), winter cherry (WC), oregano (ORE), holy basil (HB), gooseberry (GB), spearmint (SM) and common basil (CB). (B) Alterations in GSTP1 protein levels. Western blot analysis was performed at different times after exposing HT29 cells to ethanolic plant extracts. The numbers above each blot indicate fold changes in GSTP1 protein relative to the control. (C) GSTP1 activity and protein levels following treatment of HPBLs with the ethanolic extracts from neem and holy basil for $24 \mathrm{~h}$. 
The kinetics of GST P1 protein accumulation in the presence of ethanolic extracts was gradual, with the 1.5- to 2-fold increase reached at $72 \mathrm{~h}$ (Fig. 6B); this is consistent with a similar increase in GST activity shown in Fig. 6A. Treatment of HPBLs with the ethanolic extracts from neem and holy basil leaves for $24 \mathrm{~h}$ generated a marginal increase (1.4-fold) in GSTP1 activity and protein levels (Fig. 6C). Our findings indicate that plant extracts which increased MGMT activity also possess the ability to boost the GST activity, though to a lesser extent, and are thus likely to provide dual benefits.

\section{Discussion}

The protective role of MGMT, a 21-kDa DNA repair protein, against the exogenous and endogenous alkylating agents has been studied for over two decades, however, augmentation of MGMT expression as a strategy for chemoprevention through dietary or synthetic compounds has not been investigated. MGMT is constitutively expressed with wide variation in human tissues, with the highest levels found in liver, followed by colon and lung and relatively low levels in brain and myeloid tissues $(14,43,44)$. Hepatic MGMT levels are 20-fold higher than brain or bone marrow (44). A great deal of variation in MGMT expression between individuals is also known (14). Human MGMT has been thought to be mostly a constitutive and non-inducible enzyme $(8,45)$, unlike its bacterial counterparts which participate in the adaptive response to methylating agents (46); this notion may explain the lack of efforts in targeting MGMT for chemoprevention. Nevertheless, it should be noted that, as MGMT is the first-line defense (ahead of the mismatch repair system) against alkylation DNA damage $(14,15)$, even marginal increases (2- to 3-fold) are expected to be adequate for significant protection against the mutagenic lesion. Furthermore, MGMT appears to interact physically with the proliferating cell nuclear antigen (PCNA), and polymerase $\delta(47)$, raising the possibility of a repair-related function for this protein during DNA replication.

We demonstrated small but significant and reproducible increases in MGMT activity after exposing human tumor cells and HPBLs to aqueous and ethanolic extracts prepared from numerous medicinal plants. The therapeutic potential and antioxidant properties of these plants in the Indian medical system have been well established. A brief description of the pharmacological constituents (wherever defined) and the therapeutic benefits of the plants used is warranted in the context of this study.

Neem (Azadirachta indica, Meliaceae). The beneficial properties of the neem tree have been recognized in ayurvedic medicine for hundreds of years, and have been described as a virtual living pharmacy in India (48). Nimbidin, a major crude bitter principle extracted from the oil of seed kernels of $A$. indica has demonstrated a variety of biological activity. From this crude principle several tetra and triterpenes, including nimbin, nimbinin, nimbidinin, nimbolide and nimbidic acid have been isolated (49). Anti-inflammatory, antiarthritic, hypoglycemic, insecticidal, antifungal, and antitumor and immunomodulator effects have been described for neem components $(48,50)$. Neem leaf aqueous extracts can effectively suppress oral squamous cell carcinoma induced by DMBA (36). Neem has been shown to exert its chemopreventive effects by modulating the levels of enzymes in phase-II metabolism, increasing glutathione content, and preventing cell adhesion $(51,52)$.

Holy basil (Ocimum sanctum, Labiatae). This widely studied herb has been described to possess multi-medicinal and anticarcinogenic properties (53). The active principles include the flavonoids, orientin, vicenin, eugenol (1-hydroxy-2methoxy-4-allylbenzene), ursolic acid, and a number of yet uncharacterized components (54). Ocimum extracts have been used for various ailments including bronchitis, diarrhea, skin infections and painful eye infections, and are known to possess hepatoprotective, cardioprotective, antidiabetic, and anticancer activity $(53,54)$. Besides having radioprotective effects, the Ocimum chemicals have been shown to reduce chromosome damage in bone marrow $(55,56)$, inhibit lipid peroxidation (57), enhance glutathione content on topical administration, and increase the antioxidant enzyme activities (58).

Winter cherry (Withania somnifera, Solanaceae). Also called Indian ginseng or ashwagandha, the roots of this shrub contain several alkaloids (withanine, somniferine, tropine, pseudotropine and anaferine) which appear to underlie many of its medicinal properties (59). Historically, the plant has been used for over 3000 years as an aphrodisiac, liver tonic, antiinflammatory agent, astringent, and treatment of bronchitis, asthma, ulcers, and senile dementia. Clinical trials and animal research support the use of ashwaganda for anxiety, cognitive and neurological disorders, and Parkinson's disease $(60,61)$. The Withania components have been shown to inhibit tumor metastasis (62), attenuate forestomach and skin carcinogenesis (63), and modulate phase-I and phase-II enzymes beneficially for chemoprevention (64).

Indian gooseberry (Emblica officinalis, Euphorbiaceae). Also called amla, the fruits of this plant contain high levels of antioxidants such as vitamin C, quercitin, ellagic acid, chebulinic acid and isostrictinin (65). Inhibition of DMBAinduced skin cancer (66) and reduction of oxidative stress in experimental diabetes (67) by gooseberry extracts are representative examples of its therapeutic benefits. Among the other plants tested, oregano (Origanum majorana), common basil (Ocimum basilicum) and spearmint (Mentha viridis) belong to the mint family (Labiatae). They contain aromatic oils such as thymol, eugenol, limonene, carvacrol, and rosmarinic acid $(68,69)$, which possess strong antioxidant properties.

We observed a significant and time-dependent increase of MGMT activity in HPBLs and tumor cell lines by the phytochemicals. In this regard, the ethanolic constituents from holy basil and neem, followed by winter cherry, and oregano, in that rank order, were most efficient in raising the MGMT gene expression. The plant compounds induced a maximum of 3-fold enhancement in MGMT activity in tumor cell lines at $72 \mathrm{~h}$. In vitro culture of HPBLs in the presence of neem and holy basil extracts elicited a reproducible 2-fold induction of MGMT activity and protein levels. This upregulation was accompanied by proportionate increases in MGMT mRNA, again suggesting a transcriptional regulation of the gene. Our 
observations of the simultaneous but limited induction of GSTP1 with that of MGMT, and the apparent transcriptional regulation of the latter by the plant extracts point to the putative antioxidative responsiveness of the alkyltransferase gene for the first time.

It is well established that the endogenous antioxidant defense systems comprising the thiol-containing tripeptide glutathione (GSH), the enzymes involved in the biosynthesis and metabolism of GSH, including the GSTs, respond to polyphenolic antioxidant compounds present in a wide variety of plants $(42,70)$. Analysis of promoter regions of GSTs and other enzymes involved in phase-II metabolism has shown the presence of consensus sequences such as the xenobiotic response elements and antioxidant/electrophil response elements (AREs/EpREs) that are involved in their transcriptional regulation by the phytochemicals. The transcription factor, nuclear factor E2-related factor 2 (Nrf2) is closely involved in this mechanism; Nrf2 is normally bound to the Kelch-like ECH protein 1 (Keap1) in the cytoplasm. The antioxidants may disrupt the Keap-Nrf2 complex, allowing Nrf2 to translocate to the nucleus and mediate expression of phase II genes via interaction with the ARE (70). Our findings raise the possibility of the presence of ARE/EpRElike sequences in MGMT regulatory sequences. However, to date, elements responsive to plant antioxidants have not been found or explored in the human MGMT promoter (71). Future research in this direction should help to uncover the mechanisms by which the flavonoids and chemopreventative compounds modulate the MGMT gene, besides shedding light on the modulation of MGMT activity during oxidative stress.

In conclusion, we provided the first evidence for the enhancement of MGMT activity by compounds present in neem, holy basil and other herbal extracts. It is possible that common classes of chemicals present in these plants are responsible for the activation of the MGMT gene. When identified and purified, these components could serve as dietary supplements for significant upregulation of MGMT expression in human tissues, and consequently reduce cancer risk. Such an approach may also have applications in the ongoing bone marrow protection strategies against the $\mathrm{BG}^{+}$ alkylator combinations $(32,33)$. However, because, the crude herbal components are polyfunctional with multiple beneficial effects including GST activation, we are currently testing the ability of neem and holy basil compounds to enhance MGMT activity and retard toxicity induced by clinically used alkylating agents in animal tissues.

\section{Acknowledgements}

This work was supported by grants to K.S.S. from the National Institutes of Health (RO1 CA97343), Women's Health Research Institute of Amarillo, and the Association of Research for Childhood Cancer. We thank Dr Francis Ali-Osman for providing the UW228 cell line.

\section{References}

1. Mitra S and Kaina B: Regulation of repair of alkylation damage in mammalian genomes. Prog Nucleic Acid Res Mol Biol 44: 109-142, 1993.
2. Goldman R and Shields PG: Food mutagens. J Nutr 133 (suppl 3): S965-S973, 2003.

3. Bailey GS and Williams DE: Potential mechanisms for foodrelated carcinogens and anti-carcinogens. Food Tech 47: 105-118, 1994.

4. Hecht SS: Biochemistry, biology, and carcinogenicity of tobaccospecific N-nitrosamines. Chem Res Toxicol 11: 559-603, 1998.

5. Wang M, Cheng G, Sturla SJ, Shi Y, McIntee EJ, Villalta PW, Upadhyaya P and Hecht SS: Identification of adducts formed by pyridyloxobutylation of deoxyguanosine and DNA by 4(acetoxymethylnitrosamino)-1-(3-pyridyl)-1-butanone, a chemically activated form of tobacco specific carcinogens. Chem Res Toxicol 16: 616-626, 2003.

6. Singer B: Correlations between sites of chemical modification of DNA, repair, and carcinogenesis. Princess Takamatsu Symp 12: 117-137, 1982.

7. Margison GP, Santibanez Koref MF and Povey AC: Mechanisms of carcinogenicity/chemotherapy by $\mathrm{O}^{6}$-methylguanine. Mutagenesis 17: 483-487, 2002.

8. Pegg AE: Mammalian $\mathrm{O}^{6}$-alkylguanine-DNA alkyltransferase: regulation and importance in response to alkylating carcinogenic and therapeutic agents. Cancer Res 50: 6119-6129, 1990.

9. Singer B: O-alkyl pyrimidines in mutagenesis and carcinogenesis: occurrence and significance. Cancer Res 46: 4879-4885, 1986.

10. Kang H, Konishi $\mathrm{C}$, Kuroki $\mathrm{T}$ and Huh N: Detection of $\mathrm{O}^{6}-$ methylguanine, $\mathrm{O}^{4}$-methylthymine and $\mathrm{O}^{4}$-ethylthymine in human liver and peripheral blood leukocyte DNA. Carcinogenesis 16: 1277-1280, 1995.

11. Povey AC, Hall CN, Badawi AF, Cooper DP and O'Connor PJ: Elevated levels of the pro-carcinogenic adduct, $\mathrm{O}^{6}$-methylguanine, in normal DNA from the cancer prone regions of the large bowel. Gut 47: 362-365, 2000.

12. Rydberg B and Lindahl T: Nonenzymatic methylation of DNA by the intracellular methyl group donor S-adenosyl-L-methionine is a potentially mutagenic reaction. EMBO J 1: 211-216, 1982.

13. Shuker DE and Margison GP: Nitrosated glycine derivatives as a potential source of $\mathrm{O}^{6}$-methylguanine in DNA. Cancer Res 57: 366-369, 1997.

14. Margison GP, Povey AC, Kaina B and Santibanez Koref MF: Variability and regulation of $\mathrm{O}^{6}$-alkylguanine-DNA alkyltransferase. Carcinogenesis 24: 625-635, 2003.

15. Pegg AE: Repair of $\mathrm{O}^{6}$-alkylguanine by alkyltransferases. Mutat Res 462: 83-100, 2000.

16. Gerson SL: MGMT: its role in cancer aetiology and cancer therapeutics. Nat Rev Cancer 4: 296-307, 2004.

17. Dolan ME and Pegg AE: $\mathrm{O}^{6}$-benzylguanine and its role in chemotherapy. Clin Cancer Res 3: 837-847, 1997.

18. Sekiguchi M and Sakumi K: Roles of DNA repair methyltransferase in mutagenesis and carcinogenesis. Jpn J Hum Genet 42: 389-399, 1997.

19. Sekiguchi M and Sanada M: Alkylation carcinogenesis in mice with altered levels of DNA repair methyltransferase. Prog Exp Tumor Res 35: 25-36, 1999.

20. Reese JS, Allay E and Gerson SL: Overexpression of human $\mathrm{O}^{6}$-alkylguanine DNA alkyltransferase (AGT) prevents $\mathrm{MNU}$ induced lymphomas in heterozygous p53 deficient mice. Oncogene 20: 5258-5263 2001.

21. Liu L, Qin X and Gerson SL: Reduced lung tumorigenesis in human methylguanine DNA - methyltransferase transgenic mice achieved by expression of transgene within the target cell. Carcinogenesis 20: 279-284, 1999.

22. Zhou ZQ, Manguino D, Kewitt K, Intano GW, McMahan CA, Herbert DC, Hanes M, Reddick R, Ikeno Y and Walter CA: Spontaneous hepatocellular carcinoma is reduced in transgenic mice overexpressing human $\mathrm{O}^{6}$-methylguanine-DNA methyltransferase. Proc Natl Acad Sci USA 98: 12566-12571, 2001 .

23. Anisimov VN: Aging and cancer in transgenic and mutant mice. Front Biosci 8: S834-S902, 2003.

24. Kohya N, Kitajima Y, Kitahara K and Miyazaki K: Mutation analysis of K-ras and beta-catenin genes related to $\mathrm{O}^{6}$-methylguanin-DNA methyltransferase and mismatch repair protein status in human gallbladder carcinoma. Int J Mol Med 11: 65-99, 2003.

25. Park TJ, Han SU, Cho YK, Paik WK, Kim YB and Lim IK: Methylation of $\mathrm{O}^{6}$-methylguanine-DNA methyltransferase gene is associated significantly with K-ras mutation, lymph node invasion, tumor staging, and disease free survival in patients with gastric carcinoma. Cancer 92: 2760-2768, 2001. 
26. Yin D, Xie D, Hofmann WK, Zhang W, Asotra K, Wong R, Black KL and Koeffler HP: DNA repair gene $\mathrm{O}^{6}$-methylguanine-DNA methyltransferase: promoter hypermethylation associated with decreased expression and G:C to A:T mutations of p53 in brain tumors. Mol Carcinog 36: 23-31, 2003.

27. Lees NP, Harrison KL, Hall CN, Margison GP and Povey AC: Reduced MGMT activity in human colorectal adenomas is associated with K-ras GC->AT transition mutations in a population exposed to methylating agents. Carcinogenesis 25: 1243-1247, 2004.

28. Zaidi NH, Pretlow TP, O'Riordan MA, Dumenco LL, Allay E and Gerson SL: Transgenic expression of human MGMT protects against azoxymethane-induced aberrant crypt foci and $\mathrm{G}$ to $\mathrm{A}$ mutations in the K-ras oncogene of mouse colon. Carcinogenesis 16: 451-456, 1995.

29. Allay E, Veigl M and Gerson SL: Mice over-expressing human $\mathrm{O}^{6}$ alkylguanine-DNA alkyltransferase selectively reduce $\mathrm{O}^{6}$ methylguanine mediated carcinogenic mutations to threshold levels after N-methyl-N-nitrosourea. Oncogene 18: 3783-3787, 1999.

30. Shen J, Terry MB, Gammon MD, Gaudet MM, Teitelbaum SL, Eng SM, Sagiv SK, Neugut AI and Santella RM: MGMT genotype modulates the associations between cigarette smoking, dietary antioxidants and breast cancer risk. Carcinogenesis 26 : 2131-2137, 2005.

31. Chae MH, Jang JS, Kang HG, Park JH, Park JM, Lee WK, Kam S, Lee EB, Son JW and Park JY: ${ }^{6}$-alkylguanine-DNA alkyltransferase gene polymorphisms and the risk of primary lung cancer. Mol Carcinog 45: 239-249, 2006.

32. Chinnasamy D, Fairbairn LJ, Neuenfeldt J, Treisman JS, Hanson JP Jr, Margison GP and Chinnasamy N: Lentivirusmediated expression of mutant MGMTP140K protects human $\mathrm{CD} 34^{+}$cells against the combined toxicity of O6-benzylguanine and 1,3-bis(2-chloroethyl)-nitrosourea or temozolomide. Hum Gene Ther 15: 758-769, 2004.

33. Kreklau EL, Pollok KE, Bailey BJ, Liu N, Hartwell JR, Williams DA and Erickson LC: Hematopoietic expression of $\mathrm{O}^{6}$-methylguanine DNA methyltransferase-P140K allows intensive treatment of human glioma xenografts with combination $\mathrm{O}^{6}$-benzylguanine and 1,3-bis-(2-chloroethyl)-1-nitrosourea. Mol Cancer Ther 2: 1321-1329, 2003.

34. Surh YJ, Kundu JK, Na HK and Lee JS: Redox-sensitive transcription factors as prime targets for chemoprevention with anti-inflammatory and antioxidative phytochemicals. J Nutr 135 (suppl 12): S2993-S3001, 2005

35. Mukherjee PK and Wahile A: Integrated approaches towards drug development from Ayurveda and other Indian system of medicines. J Ethnopharmacol 103: 25-35, 2006.

36. Subapriya R, Velmurugan B and Nagini S: Modulation of xenobiotic-metabolizing enzymes by ethanolic neem leaf extract during hamster buccal pouch carcinogenesis. J Exp Clin Cancer Res 24: 223-230, 2005

37. Karthikeyan K, Ravichandran $\mathrm{P}$ and Govindasamy $\mathrm{S}$ : Chemopreventive effect of Ocimum sanctum on DMBAinduced hamster buccal pouch carcinogenesis. Oral Oncol 35: $112-119,1999$

38. Srivenugopal KS, Mullapudi SR, Shou J, Hazra TK and AliOsman F: Protein phosphorylation is a regulatory mechanism for $\mathrm{O}^{6}$-alkylguanine-DNA alkyltransferase in human brain tumor cells. Cancer Res 60: 282-287, 2000

39. Colovai AI, Stoica A, Cinca SA, Marin M, Gruia M, Condrea I, Petrescu D and Dutu R: Glutathione S-transferase activity in human breast tumors. Neoplasma 39: 249-254, 1992.

40. Tanaka S, Kobayashi I, Utsuki S, Oka H, Yasui Y and Fujii K: Down-regulation of $\mathrm{O}^{6}$-methylguanine-DNA methyltransferase gene expression in gliomas by platinum compounds. Oncol Rep 14: $1275-1280,2005$.

41. Mullapudi SR, Ali-Osman F, Shou J and Srivenugopal KS: DNA repair protein $\mathrm{O}^{6}$-alkylguanine-DNA alkyltransferase is phosphorylated by two distinct and novel protein kinases in human brain tumour cells. Biochem J 351: 393-402, 2000.

42. Pool-Zobel B, Veeriah S, and Bohmer FD: Modulation of xenobiotic metabolisiing enzymes by anticarcinogens - focus on glutathione S-transferases and their role as targets of dietary chemoprevention in colorectal carcinogenesis. Mutat Res 591: 74-92, 2005 .

43. Grafstrom RC, Pegg AE, Trump BF and Harris CC: $\mathrm{O}^{6}$-alkylguanine-DNA alkyltransferase activity in normal human tissues and cells. Cancer Res 44: 2855-2857, 1984.
44. Gerson SL, Trey JE, Miller K and Berger NA: Comparison of $\mathrm{O}^{6}$-alkylguanine-DNA alkyltransferase activity based on cellular DNA content in human, rat and mouse tissues. Carcinogenesis 7: 745-749, 1986

45. Frosina $\mathrm{G}$ and Abbondandolo A: The current evidence for an adaptive response to alkylating agents in mammalian cells, with special reference to experiments with in vitro cell cultures. Mutat Res 154: 85-100, 1985.

46. Lindahl T, Sedgwick B, Sekiguchi M and Nakabeppu Y: Regulation and expression of the adaptive response to alkylating agents. Annu Rev Biochem 57: 133-157, 1988.

47. Niture SK, Doneanu CE, Velu CS, Bailey NI and Srivenugopal KS: Proteomic analysis of human $\mathrm{O}^{6}$-methylguanine-DNA methyltransferase by affinity chromatography and tandem mass spectrometry. Biochem Biophys Res Commun 337: 1176-1184, 2005.

48. Subapriya R and Nagini S: Medicinal properties of neem leaves: a review. Curr Med Chem Anticancer Agents 5: 149-156, 2005.

49. Siddiqui BS, Afshan F, Gulzar T and Hanif M: Tetracyclic triterpenoids from the leaves of Azadirachta indica. Phytochemistry 65: 2363-2367, 2004.

50. Subapriya R, Kumaraguruparan R, Chandramohan KV and Nagini S: Chemoprotective effects of ethanolic extract of neem leaf against MNNG-induced oxidative stress. Pharmazie 58: 512-517, 2003

51. Hanachi P, Fauziah O, Peng LT, Wei LC, Nam LL and Tian TS The effect of Azadirachta indica on distribution of antioxidant elements and glutathione S-transferase activity in the liver of rats during hepatocarcinogenesis. Asia Pac J Clin Nutr 13 (suppl): S170, 2004

52. Dasgupta T, Banerjee S, Yadava PK and Rao AR: Chemopreventive potential of Azadirachta indica (Neem) leaf extract in murine carcinogenesis model systems. J Ethnopharmacol 92: 23-36, 2004

53. Prakash P and Gupta N: Therapeutic uses of Ocimum sanctum Linn (Tulsi) with a note on eugenol and its pharmacological actions: a short review. Indian J Physiol Pharmacol 49: 125-131, 2005.

54. Gupta SK, Prakash J and Srivastava S: Validation of traditional claim of Tulsi, Ocimum sanctum Linn. as a medicinal plant. Indian J Exp Biol 40: 765-773, 2002

55. Uma Devi P, Ganasoundari A, Vrinda B, Srinivasan KK and Unnikrishnan MK: Radiation protection by the ocimum flavonoids orientin and vicenin: mechanisms of action. Radiat Res 154: 455-460, 2000.

56. Ganasundari A, Devi PU and Rao MN: Protection against radiation-induced chromosome damage in mouse bone marrow by Ocimum sanctum. Mutat Res 373: 271-276, 1997.

57. Geetha RK and Vasudevan DM: Inhibition of lipid peroxidation by botanical extracts of Ocimum sanctum: in vivo and in vitro studies. Life Sci 76: 21-28, 2004.

58. Prashar R, Kumar A, Banerjee S and Rao AR: Chemopreventive action by an extract from Ocimum sanctum on mouse skin papillomagenesis and its enhancement of skin glutathione Stransferase activity and acid soluble sulfydryl level. Anticancer Drugs 5: 567-572, 1994.

59. Mishra LC, Singh BB and Dagenais S: Scientific basis for the therapeutic use of Withania somnifera (ashwagandha): a review. Altern Med Rev 5: 334-346, 2000.

60. Gandhi A: Comparitive pharmacological investigation of ashvagandha and ginseng. J Ethnopharmacol 3: 131-135, 1994.

61. Gupta SK, Dua A and Vohra BP: Withania Somnifera attenuates antioxidant defense in aged spinal cord and inhibits copper induced lipid peroxidation and protein oxidative modifications. Drug Metabol Drug Interact 19: 211-222, 2003

62. Leyon PV and Kuttan G: Effect of Withania Somnifera on B16F-10 melanoma induced metastasis in mice. Phytother Res 18: 118-122, 2004.

63. Davis L and Kuttan G: Effect of Withania Somnifera on DMBA induced carcinogenesis. J Ethnopharmacol 75: 165-168, 2001

64. Padmavati B, Rath PC, Rao AR and Singh RP: Roots of Withania somnifera inhibit forestomach and skin carcinogenesis in mice. Evid Based Complement Alternate Med 2: 99-105, 2005.

65. Zhang YJ, Nagao T, Tanaka T, Yang CR, Okabe H and Kouno I: Antiproliferative activity of the main constituents from Phyllanthus emblica. Biol Pharm Bull 27: 251-255, 2004

66. Sanchetti G, Jindal A, Kumari R, and Goyal PK: Chemopreventative action of emblica officinalis on skin carcinogenesis in mice. Asian Pac J Cancer Prev 6: 197-201, 2005. 
67. Rao TP, Sakaguchi N, Junjea LR, Wada E and Yokozawa T: Amla (Emblica officinalis Gaertn.) extracts reduce oxidative stress in streptozotocin-induced diabetic rats. J Med Food 8: 362-368, 2005.

68. Vagi E, Rapavi E, Hadolin M, Vasarhelyine Peredi K, Balazs A, Blazovics A and Simandi B: Phenolic and triterpenoid antioxidants from Origanum majorana herb and extracts obtained with different solvents. Agri Food Chem 53: 17-21, 2005.
69. Yu TW, Xu M and Dashwood RH: Antimutagenic activity of spearmint. Environ Mol Mutagen 44: 387-393, 2004.

70. Moskaug JO, Carlsen H, Myhrstad CW and Blomhoff R: Polyphenols and glutathione synthesis regulation. Am J Clin Nutr 81 (suppl): S277-S283, 2005.

71. Harris LC, Potter PM, Tano K, Shiota S, Mitra S and Brent TP Characterization of the promoter region of the human $\mathrm{O}^{6}$ methylguanine-DNA methyltransferase gene. Nucleic Acids Res 19: 6163-6167, 1991. 